Vol 1 No 11, November 2021

E-ISSN: 2775-6440 | P-ISSN: 2808-7208

Jurnal Homepage https://fusion.rifainstitute.com

\title{
EVALUASI PEMBERLAKUAN HAK YANG TIDAK DIDAPAT NARAPIDANA SEUMUR HIDUP PADA LAPAS KELAS I SURABAYA
}

\author{
Yahya Rofi Triatmaja, Mitro Subroto \\ Politeknik Ilmu Pemasyarakatan \\ Email:yyrt6047@gmail.com,mitro.subroto@gmail.com
}

\begin{abstract}
Each type of violation has its own term of punishment. For crimes such as theft and robbery, it ranges from 5 - 10 years in prison. However, it is different with the act of drug abuse and murder which gets a life sentence. For those who are still laymen, life imprisonment means that the convict spends the rest of his life in a correctional institution. But in reality it is not so. Life sentences range from 20-25 years. The research method used is descriptive qualitative. In this approach, the research procedure produces descriptive data in the form of written or spoken words from the observed people and observed behavior. The qualitative approach is carried out in natural conditions and is discovery. In a qualitative approach, the researcher is the main instrument. This approach is used to review the quality of the implementation of rights that are not obtained by life inmates in Class I prisons in Surabaya, the results are then described in detail. Data collection techniques used were interviews to obtain information on the implementation of rights that were not obtained by lifelong prisoners and documentation to obtain references. The results of this study are in the form of an explanation of the implementation of rights that are not obtained by lifelong prisoners at the Class I prison in Surabaya.
\end{abstract}

Keywords: Lapas Kelas I Surabaya, Life Imprisonment, Non-receivable rights

\begin{abstract}
Abstrak
Setiap jenis pelanggaran memiliki masa hukuman masing-masing. Untuk tindak kriminal seperti pencurian dan perampokan berkisar antara 5-10 tahun penjara. Namun lain halnya dengan tindakan penyalahgunaan narkoba dan pembunuhan yang mendapat masa hukuman seumur hidup. Bagi yang masih awam, hukuman seumur hidup diartikan bahwa narapidana tersebut menghabiskan seluruh sisa hidupnya di dalam lembaga pemasyarakatan. Namun pada kenyataannya tidaklah demikian. Masa hukuman seumur hidup berkisar antara 20-25 tahun. Metode penelitian yang digunakan adalah kualitatif deskriptif. Pada pendekatan ini, prosedur penelitian menghasilkan data deskriptif berupa kata-kata tertulis atau lisan dari orang-orang yang diamati dan perilaku yang diamati. Pendekatan kualitatif dilakukan pada kondisi alamiah dan bersifat penemuan. Dalam pendekatan kualitatif, peneliti sebagai instrumen utama. Pendekatan ini digunakan untuk meninjau kualitas dari pelaksanaan hak-hak yang tidak didapat narapidana seumur hidup di Lapas Kelas I Surabaya yang kemudian hasilnya
\end{abstract}


dideskripsikan secara terperinci Penelitian ini dilakukan dengan tujuan meninjau pelaksanaan hak yang tidak didapat narapidana seumur hidup pada Lapas Kelas I Surabaya. Teknik pengumpulan data yang dilakukan yakni wawancara untuk memperoleh keterangan pelaksanaan hak yang tidak didapat narapidana seumur hidup dan dokumentasi untuk mendapatkan referensi. Hasil penelitian ini berupa pemaparan terlaksananya hak-hak yang tidak didapat narapidana seumur hidup pada Lapas Kelas I Surabaya.

Kata kunci: Hak yang Tidak Didapat, Lapas Kelas I Surabaya, Narapidana Seumur Hidup

Diterima: 19-10-2021Ｄirevisi: 13-11-2021Ｄiterbitkan: 20-11-2021

\section{Pendahuluan}

Indonesia merupakan negara hukum (Rosyid Al Atok, 2016) yang mengharuskan setiap warga negaranya bertindak sesuai hukum yang berlaku sehingga tatanan kehidupan berbangsa dan bernegara tetap tertib. Meskipun pada praktiknya masih ditemui hukum yang tumpul ke atas namun tajam ke bawah. Hal tersebut bertentangan dengan sila ke-5 Pancasila yakni Keadilan Sosial Bagi Seluruh Rakyat Indonesia. Yang sesuai dengan sila tersebut adalah hukum yang tidak pandang bulu (Asshiddiqie, 2017). Apa pun jenis kalangannya, jika melakukan kesalahan harus ditindak sebagaimana hukum yang berlaku. Seperti yang diketahui di Indonesia terdapat hukum pidana dan hukum perdata. Hukum pidana adalah hukum yang menindaklanjuti kriminalitas dengan ancaman hukum pidana (Republik Indonesia, 1981) salah satunya kasus pembunuhan. Sedangkan hukum perdata adalah hukum yang menindaklanjuti kriminalitas yang berhubungan dengan hal administratif (Indonesia, 1947) seperti sengketa. Namun sebelum menuju ke ranah hukum, umumnya menempuh mediasi terlebih dahulu atau dikenal dengan istilah secara kekeluargaan.

Mediasi tak selalu membuahkan hasil. Terkadang salah satu pihak masih keberatan yang mengharuskan berlanjut ke meja hijau dan berakibat vonis pidana. Seseorang yang mendapatkan vonis pidana disebut narapidana dan ditempatkan di lembaga pemasyarakatan (Abdullah, 2016). Lembaga pemasyarakatan adalah lembaga khusus yang dibentuk negara di bawah naungan Kementrian Hukum dan Hak Asasi Manusia serta Badan Pembinaan Hukum Nasional. Lembaga pemasyarakatan terdiri dari 4 kelas yakni Kelas I, Kelas IIA, Kelas IIB, dan Kelas III (Priyatno, 2013). Penggolongan kelas lembaga pemasyarakatan disesuaikan dengan kapasitas, kedudukan, dan kegiatan kerja. Tujuan dibentuknya lembaga pemasyarakatan adalah untuk membina narapidana agar memiliki kesadaran hukum. Sehingga saat dibebaskan mampu menciptakan ketertiban dan keamanan di lingkungan domisilinya. Jika seseorang pernah berstatus sebagai narapidana, bukan tidak mungkin akan dipandang sebelah mata oleh lingkungannya. Sehingga peran lembaga pemasyarakatan di sini juga membina psikis narapidana sehingga mampu menampik pandangan publik terhadap dirinya. Pada hakikatnya, narapidana bukanlah seseorang yang sama sekali tidak tahumenahu tentang hukum dan perundangan negara. Mereka sadar betul mengenai hukum, 
perundangan, dan norma yang berlaku di negara. Namun ketiga hal tersebut terpaksa dilanggar karena hal mendesak seperti masalah ekonomi. Ditinjau dari sudut pandang kemanusiaan memanglah hal yang membuat iba, namun jika ditinjau dari sudut pandang hukum tetaplah pelanggaran hukum yang patut ditindaklanjuti. Tindakan pelanggaran hukum yang dilakukan juga beragam seperti pencurian, perampokan, penipuan, penyalahgunaan narkoba, hingga pembunuhan (Chintia et al., 2019).

Setiap jenis pelanggaran memiliki masa hukuman masing-masing. Untuk tindak kriminal seperti pencurian dan perampokan berkisar antara 5-10 tahun penjara. Namun lain halnya dengan tindakan penyalahgunaan narkoba dan pembunuhan yang mendapat masa hukuman seumur hidup. Bagi yang masih awam, hukuman seumur hidup diartikan bahwa narapidana tersebut menghabiskan seluruh sisa hidupnya di dalam lembaga pemasyarakatan. Namun pada kenyataannya tidaklah demikian. Masa hukuman seumur hidup berkisar antara $20-25$ tahun. Contoh kasus faktual dengan masa hukuman seumur hidup adalah di Lapas Kelas I Surabaya yakni penyelundupan ganja seberat 10 kilogram oleh kurir narkoba (Radlis. M, 2018). Kurir tersebut dikendalikan oleh salah satu narapidana Lapas Kelas I Surabaya. Semua pihak yang terlibat dalam transaksi dan pendistribusian narkoba terancam hukuman pidana seumur hidup (Hidriyah, 2018). Kendati demikian, masing-masing narapidana tetap melaksanakan kewajibannya selama kegiatan pembinaan dan mendapat hak sebagaimana perundangan yang berlaku. Beberapa hak narapidana adalah asimilasi dan cuti mengunjungi keluarga. Asimilasi adalah kegiatan membaurkan narapidana ke kehidupan bermasyarakat sebagai bukti bahwa mereka berhasil dibina di dalam lembaga pemasyarakatan (Trisnawati, 2020). Namun tidak dengan narapidana seumur hidup. Narapidana ini tidak mendapatkan haknya melakukan asimilasi dengan suatu pertimbangan. Yakni tindak kriminal yang dilakukan narapidana seumur hidup tergolong membahayakan publik. Seperti pembunuhan dan penyalahgunaan narkoba. Karena dikhawatirkan masih memiliki keinginan untuk melakukan aksi serupa yang mana sangat berbahaya bagi masyarakat. Misalnya saja narapidana kasus narkoba, masih sangat dimungkinkan menghasut masyarakat untuk melakukan transaksi narkoba. Karena sebenarnya zat-zat yang tergolong dalam narkoba hanya boleh digunakan oleh tenaga medis sebagai anestesi dengan dosis yang ketat. Narapidana seumur hidup juga tidak diperkenankan ditemui dan menemui pihak keluarganya. Karena dikhawatirkan semakin menyebarluaskan transaksi narkoba.

Berdasarkan uraian di atas, penulis memutuskan melakukan penelitian tentang hak-hak yang tidak didapat narapidana hukuman seumur hidup di Lapas Kelas I Surabaya. Karena lapas tersebut tergolong lapas berpredikat baik, namun beberapa tahun silam masih terjadi kebobolan transaksi narkoba yang dikendalikan oleh narapidana di dalamnya. Tujuan penelitian ini adalah meninjau apakah hak-hak yang tidak didapat narapidana hukuman seumur hidup benar terlaksana sebagaimana mestinya. Hasil penelitian ini adalah bukti terlaksana tidaknya hak-hak yang tidak didapat narapidana seumur hidup di Lapas Kelas I Surabaya. Manfaat penelitian bagi penulis adalah menambah wawasan agar kelak saat bertugas mampu menjaga 
terlaksananya segala hak dan kewajiban narapidana untuk meminimalisir pelanggaran dan bisa digunakan sebagai acuan untuk penelitian serupa di masa mendatang. Manfaat penelitian bagi Politeknik Ilmu Pemasyarakatan adalah menjembatani kerjasama antara institusi dan lembaga pemasyarakatan terkait penegakan undang-undang pemasyarakatan. Manfaat penelitian bagi Lapas Kelas I Surabaya adalah menjadi bahan evaluasi maupun pertimbangan agar sistem keamanan lapas lebih diperketat.

\section{Metode Penelitian}

Metode penelitian yang digunakan adalah kualitatif deskriptif. Pendekatan kualitatif adalah suatu proses penelitian dan pemahaman yang menyelidiki suatu fenomena sosial dan masalah manusia. Pada pendekatan ini, prosedur penelitian menghasilkan data deskriptif berupa kata-kata tertulis atau lisan dari orang-orang yang diamati dan perilaku yang diamati. Pendekatan kualitatif dilakukan pada kondisi alamiah dan bersifat penemuan. Dalam pendekatan kualitatif, peneliti sebagai instrumen utama. Pendekatan ini digunakan untuk meninjau kualitas dari pelaksanaan hak-hak yang tidak didapat narapidana seumur hidup di Lapas Kelas I Surabaya yang kemudian hasilnya dideskripsikan secara terperinci (Sugiyono, 2012). Data yang digunakan yakni data primer dan data sekunder. Data primer adalah data yang langsung diperoleh dari narasumber yakni berupa hasil wawancara dengan petugas pemasyarakatan Lapas Kelas I Surabaya. Sedangkan data sekunder adalah data yang didapat dari narasumber atau sumber lainnya namun diolah kembali oleh penulis (Ardianto, 2019). Teknik pengumpulan data primer yang digunakan adalah wawancara. Yakni mewawancarai petugas pemasyarakatan terkait pelaksanaan hakhak yang tidak didapat narapidana seumur hidup. Untuk data sekunder diperoleh dengan cara dokumentasi yakni berupa referensi jurnal, artikel, dan buku untuk penyusunan jurnal.

Adapun pertanyaan wawancara yang diajukan kepada petugas pemasyarakatan Lapas Kelas I Surabaya yakni sebagai berikut: Bagaimana pelaksanaan hak yang tidak didapat narapidana seumur hidup kurang lebih 5 tahun terakhir pada Lapas Kelas I Surabaya? Bagaimana dampak yang ditimbulkan terkait kasus tahun 2017 tentang penyelundupan ganja yang di gembong oleh salah satu narapidana Lapas Kelas I Surabaya?

\section{Hasil dan Pembahasan}

Di dalam Lembaga Pemasyarakatan terdapat beberapa penggolongan narapidana berdasarkan beberapa kriteria, antara lain: Umur, jenis kelamin, lama pidana yang dijatuhkan, jenis kejahatan lainnya, dan kriteria lainnya. Dalam hal ini, pengertian dari pidana seumur hidup adalah pidana penjara sepanjang narapidana masih hidup dan hukumannya baru akan berakhir setelah kematian.

Setiap narapidana memiliki hak dan kewenangannya. Namun berdasarkan hasil penelitian yang diperoleh penulis setelah melakukan wawancara didapati bahwa:

1. Narapidana seumur hidup di Lapas Kelas I Surabaya tidak melanggar hak yang memang tidak patut didapatkan 
2. Dampak kasus tahun 2017 terkait penyelundupan ganja terhadap narapidana lain yakni tidak terjadi lagi kasus serupa hingga saat ini karena mengetahui konsekuensi yang didapatkan.

\section{Pembahasan}

Bagian fundamental dari sistem pemidanaan adalah menerapkan suatu sanksi. Lembaga pemasyarakatan secara ideal berperan untuk memasyarakatkan narapidana kembali dengan membina para warga binaan agar dapat diterima kembali. Tujuan lembaga ini adalah perubahan sifat, cara berfikir serta perilaku, proses interaksi edukatif harus dibangun. Interaksi edukatif yang intensif sangat diperlukan, agar secara kolektif tumbuh kesadaran dari para warga binaan tentang perilaku yang seharusnya dilakukan. Begitulah setidaknya fungsi lapas dalam tataran ideal. Lembaga pemasyarakatan adalah sebagai tempat pembinaan dengan tujuan agar narapidana dapat kembali menjadi warga masyarakat yang baik yang menyadari segala kesalahannya serta dapat kembali ke dalam masyarakat dengan menjadi manusia yang baik. Pembinaan narapidana adalah suatu sistem, maka pembinaan narapidana mempunyai beberapa komponen yang bekerja saling berkaitan untuk satu tujuan. Pada tahun 1964 sistem pembinaan bagi narapidana telah berubah secara mendasar yaitu dari sistem kepenjaraan menjadi sistem pemasyarakatan. Sistem pemasyarakatan adalah suatu tatanan mengenai arah dan batas serta cara pembinaan narapidana berdasarkan Pancasila yang dilaksanakan secara terpadu antara pembina, yang dibina dan masyarakat untuk meningkatkan kualitas narapidana agar menyadari kesalahan, memperbaiki diri, dan tidak mengulangi lagi tindak pidana sehingga dapat diterima kembali oleh lingkungan masyarakat, dapat hidup sebagai warga yang baik dan bertanggung jawab (Priyatno, 2013). Dalam hal ini pembinaan juga dilakukan untuk narapidana seumur hidup.

Menurut peraturan perundang-undangan yang berlaku, setiap narapidana memiliki hak-hak yang sama selama menjalani masa pidananya di Lapas, termasuk narapidana seumur hidup. Hak masing-masing narapidana tersebut diatur dalam Pasal 14 ayat (1) UU Pemasyarakatan. Adapun hak-haknya meliputi hak untuk melakukan ibadah sesuai dengan agama atau kepercayaannya, memperoleh perawatan, baik perawatan rohani maupun jasmani, mendapatkan pelayanan kesehatan dan makanan yang layak, mendapatkan pendidikan dan pengajaran, menyampaikan keluhan, mendapatkan bahan bacaan dan siaran media massa yang tidak melanggar peraturan yang ada, mendapatkan upah atau premi atas pekerjaan yang dilakukan, menerima kunjungan keluarga, penasehat hukum, atau orang tertentu, mendapatkan kesempatan berasimilasi termasuk cuti keluarga, mendapatkan pengurungan hukum atau remisi, mendapatkan pembebasan bersyarat, mendapatkan cuti menjelang bebas, dan mendapatkan hak lainnya yang telah diatur dalam undang-undang.

Namun dalam penyelenggaraannya tidak semua hak dapat diberikan kepada seluruh narapidana akibat beberapa pertimbangan. Pembahasan yang pertama mengenai terlaksananya pemberlakuan hak-hak yang tidak didapat narapidana seumur hidup pada Lapas Kelas I Surabaya. Hak-hak yang dimaksud adalah tidak diperbolehkan melakukan asimilasi dan dijenguk oleh pihak keluarga. Dan hal tersebut terbukti 
sebagaimana keterangan yang diberikan petugas pemasyarakatan. Narapidana seumur hidup tidak diperbolehkan mengikuti asimilasi atau berbaur dengan masyarakat umum karena dikhawatirkan menyebar pengaruh buruk sesuai tindakan kriminal yang pernah dilakukan. Jika narapidana lain melakukan asimilasi, narapidana seumur hidup akan didampingi petugas pemasyarakatan untuk melakukan aktivitas pembinaan lainnya sehingga tidak timbul rasa iri dengan narapidana lain yang masa hukumannya berbeda. Karena hak asimilasi bagi narapidana bertujuan agar adaptif dengan lingkungan masyarakat dikarenakan menyandang status sebagai narapidana. Dan bukan rahasia lagi bahwa terkadang masih dijumpai mantan narapidana yang dipandang sebelah mata oleh publik dengan alasan takut. Padahal mantan narapidana sudah mendapat pembinaan dan pengawasan penuh ketika menjalani masa hukuman di dalam lembaga pemasyarakatan.

Kebijakan ini telah sesuai dengan Pasal 36 ayat (1) huruf c Peraturan Menteri Hukum dan Hak Asasi Manusia Republik Indonesia Nomor 21 Tahun 2013 Tentang Syarat dan Tata Cara Pemberian Remisi, Asimilasi, Cuti Mengunjungi Keluarga, Pembebasan Bersyarat, Cuti Menjelang Bebas, dan Cuti Bersyarat yang mengatur bahwa narapidana hukuman mati tidak mendapatkan hak asimilasi. Ketentuan yang mengatur bahwa narapidana seumur hidup tidak diberikan asimilasi adalah Pasal 33 Permenkumham 21/2013 yang berbunyi:

\section{Asimilasi tidak diberikan kepada Narapidana:}

a. yang terancam jiwanya; atau

b. $\quad$ yang sedang menjalani pidana penjara seumur hid

Pembahasan yang kedua yakni bahwa narapidana seumur hidup tidak diperbolehkan dijenguk kerabatnya. Hal ini dilakukan dengan tujuan meminimalisir peluang melakukan tindak kriminal serupa yang sistemnya remote, yakni dikendalikan secara jarak jauh oleh narapidana terkait di dalam lapas dan yang melakukan tindakan secara langsung adalah kerabat. Yang mana jika hal tersebut benar terjadi, pihak kerabat yang terlibat juga terancam hukuman pidana. Sehingga jika ada kerabat narapidana seumur hidup yang berkunjung ke lapas, akan dilakukan pemeriksaan secara intensif terkait barang-barang yang dibawa. Kemudian barang-barang tersebut diberikan kepada narapidana terkait oleh petugas pemasyarakatan. Sehingga tidak terjadi kontak langsung antara kerabat dan narapidana seumur hidup.

Pembahasan ketiga yakni mengenai dampak yang ditimbulkan dari kasus penyelundupan ganja pada tahun 2017. Singkat cerita ada salah satu narapidana di Lapas Kelas I Surabaya yang bertindak sebagai gembong atau otak dari transaksi ganja seberat 10 kilogram. Narapidana ini menugaskan 2 orang temannya yang biasanya menjenguk untuk melakukan transaksi ganja dikarenakan imbalan sebagai kurir ganja yang cukup menggiurkan. Kemudian ganja itu dibawa ke Lapas Kelas I Surabaya dengan kondisi terbungkus rapi dan sama sekali tidak terlihat mencurigakan. Namun setelah diperiksa oleh petugas pemasyarakatan, terbongkar bahwa bungkusan tersebut adalah ganja seberat 10 kilogram. Yang akhirnya diputuskan 2 kurir ganja divonis hukuman seumur hidup. Sedangkan gembongnya divonis pasal berlapis. Sedikit banyak para narapidana dari berbagai jenis masa hukuman mengetahui kasus ini. Dampak yang 
ditimbulkan yakni narapidana tidak melakukan aksi serupa karena konsekuensi yang diterima cukup berat. Sudah menjalani masa hukuman atas tindakan kriminalnya sendiri, jika terkena pasal berlapis akan lebih lama di dalam lapas dan mengurangi waktu berbaur dengan publik serta kerabat. Karena tujuan pembinaan di lembaga pemasyarakatan adalah agar narapidana memiliki kesadaran hukum yang tinggi setelah masa hukumannya selesai. Bukan malah menambah masa hukuman dengan melakukan tindak kriminal lainnya.

Kebijakan yang dilakukan oleh Lapas Kelas I Surabaya merupakan bentuk dari asas yang berlaku pada Lembaga Pemasyarakatan antara lain: pengayoman, pendidikan, persamaan perlakuan dan pelayanan, pembimbingan, penghormatan atas harkat dan martabat manusia, kehilangan kemerdekaan merupakan satu-satunya penderitaan, dan terjaminnya hak untuk tetap berhubungan dengan keluarga dan orang-orang tertentu. Hal ini mengindikasikan bahwa seluruh narapidana memiliki hak-hak dasar yang sama untuk dilakukan pembinaan sesuai asas yang tertera di atas. Sebagai bentuk dari asas kemerdekaan merupakan satu-satunya penderitaan, pencabutan hak asimilasi dan kunjungan keluarga menjadi hal yang krusial untuk dilakukan.

Kebijakan Lapas I Surabaya ini juga beralasan mengingat kasus pengedaran narkoba yang marak terjadi di dalam lapas akibat kontak narapidana hukuman mati dengan orang lain. Data dari Badan Narkotika Nasional (BNN) setiap tahunnya penyelundupan narkoba terus meningkat secara signifikan. Misalnya pada kasus Freddy Budiman yang telah divonis mati namun tetap mampu untuk melakukan transaksi narkoba.

Menurut kepala BNN terdapat beberapa faktor utama di balik maraknya peredaran narkoba. Penjara menjadi tempat perekrutan bagi pengedar baru narkoba dengan modus merekrut mereka dengan cara berhutang. Dalam Lembaga Pemasyarakatan, narapidana yang merupakan narapidana kasus narkoba ditempatkan pada satu tempat yang sama sehingga memudahkannya terjadi transaksi. Faktor lainnya karena kurangnya kontrol atau pengawasan dari petugas Lapas terhadap peredaran narkoba di Lapas atau Rutan dan tak jarang petugas lapas justru menjadi kaki tangan.

\section{Kesimpulan}

Kesimpulan dari penelitian yang telah dilakukan yakni sistem pembinaan di Lapas Kelas I Surabaya sudah baik. Pihak Lapas Kelas I Surabaya menjadikan kasus di tahun 2017 sebagai pembelajaran sehingga sampai saat ini tidak terdapat kasus penyelundupan serupa. Mengingat bahwa Lapas Kelas I Surabaya merupakan lembaga pemasyarakatan dengan predikat baik di Jawa Timur.

Implikasi dari penelitian yang telah dilakukan yakni upaya Lapas Kelas I Surabaya agar selalu mempertahankan sistem pembinaan yang sudah baik sehingga bisa dijadikan teladan oleh lembaga pemasyarakatan lainnya. Implikasi bagi taruna/i Politeknik Ilmu Pemasyarakatan yakni dapat menerapkan sistem yang sudah baik tersebut ketika bertuga dan penelitian ini dapat dijadikan referensi di masa mendatang. 


\section{BIBLIOGRAFI}

Abdullah, R. H. (2016). Urgensi Penggolongan Narapidana Dalam Lembaga Pemasyarakatan. Fiat Justisia:Jurnal Ilmu Hukum. https://doi.org/10.25041/fiatjustisia.v9no1.587 Google Scholar

Ardianto, Y. (2019). Memahami Metode Penelitian Kualitatif. In Djkn. Google Scholar

Asshiddiqie, J. (2017). Gagasan Negara Hukum Indonesia. Pn-Gunungsitoli. Google Scholar

Chintia, E., Nadiah, R., Ramadhani, H. N., Haedar, Z. F., Febriansyah, A., \& Rakhmawati S.Kom., M.Sc.Eng, N. A. (2019). Kasus Kejahatan Siber yang Paling Banyak Terjadi di Indonesia dan Penanganannya. Journal of Information Engineering and Educational Technology. https://doi.org/10.26740/jieet.v2n2.p6569 Google Scholar

Hidriyah, S. (2018). Mengapa Indonesia Menjadi Sasaran Sindikat Narkoba Internasional. Kajian Singkat Terhadap Isu Aktual Dan Strategis. Google Scholar

Indonesia. (1947). Kitab Undang-undang Hukum Perdata. Online. Google Scholar

Priyatno, D. (2013). Sistem Pelaksanaan Pidana Penjara di Indonesia. In Refika Aditama. Google Scholar

Radlis. M. (2018). Kurir Ganja Diancam Hukuman Penjara Seumur Hidup. Tribunnews. Google Scolar

Republik Indonesia. (1981). Kitab Undang-Undang Hukum Acara Pidana (KUHAP) (Kementerian Hukum dan HAM (ed.)). Google Scholar

Rosyid Al Atok, A. (2016). Negara Hukum Indonesia. Konsep Dan Aktualisasi Negara Hukum Pancasila. Google Scholar

Sugiyono. (2012). Metode Penelitian Kuantitatif, Kualitatif, dan $R \& D$ (22nd ed.). Alfabeta CV. Google Scholar

Trisnawati, N. A. (2020). Pemberian Asimilasi Dan Integrasi Terhadap Narapidana Dan Anak Dalam Rangka Pencegahan Dan Penanggulangan Penyebaran COVID-19 (Studi di Lembaga Pemasyarakatan Perempuan Kelas IIA Malang). Society. Google Scholar

First publication right:

Jurnal Syntax Fusion: Jurnal Nasional Indonesia

This article is licensed under:

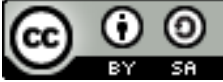

